\title{
破壊前駆過程におけるアルミナの微小塑性 ${ }^{\dagger}$
}

\author{
小川裕之计西野洋一浅野滋
}

名古屋工業大学材料工学科

J. Japan Inst. Metals, Vol. 57, No. 4 (1993), pp. 389-393

Microplasticity of Alumina in Forerunning Process of Fracture

Hiroyuki Ogawa, Yoichi Nishino and Shigeru Asano

Department of Materials Science and Engineering, Nagoya Institute of Technology, Nagoya

\begin{abstract}
Mechanical hysteresis in alumina with microcracks has been investigated by a loading-unloading test in the microstrain range around $10^{-4}$ and examined in comparison with the strain amplitude dependence of internal friction. While there remains a permanent strain after the initial loading, successive cyclic loading stabilizes the mechanical response, resulting in a single closed hysteresis loop with a symmetrical shape. Such a stabilized hysteresis loop is responsible for the internal friction based on the friction mechanism and can be attributed to the microplasticity in the forerunning process of fracture. With increasing strain amplitude, the area enclosed by the stabilized hysteresis loops increases remarkably. Since the loop area determines the energy loss per cycle, its strain amplitude dependence is considered to arise from the same origin as that of internal friction. The internal friction data have also been analyzed on the basis of the theory of microplasticity. The stress-strain responses thus obtained show that the microplastic strain of the order of $10^{-9}$ increases nonlinearly with increasing effective stress. The variation in the microplastic flow stress corresponds well to the decrease in the macroscopic fracture strength resulting from the formation of microcracks and crack propagation.
\end{abstract}

(Received November 17,1992)

Keywords: alumina ceramics, fracture, microplasticity, mechanical hysteresis, internal friction, strain amplitude dependence, nonlinear hysteretic strain

\section{I. 緒言}

セシミックスは，通常，金属のような塑性変形を起こさず， 弾性変形から直らに破壊へと移行する。したがって，セラミッ クスの破罣現象を明らかにするためには，破壊の前駆過程に括 ける変形挙動を詳細に調べることが必要となる。このような微 小なひず領域での力学応答を観測する方法として, 力学的七 ステリシスの観察や内部摩擦の振幅依存性の測定がめる.

降伏以前のひずみ領域で繰返し変形を行った場合, 応力ーひ ずみ曲線上《ヒステリシスループが形成されることがある。こ のような力学的ヒステリシスは，これ李で多くの金属・合金に ついて観察されて括り(1)-(3)，10-4 程度のひずみ領域における 微小塑性に基づく現象であることが知られている。一方，内部 摩擦の測定は $10^{-6}$ 程度のひずみ振揊のすとで行われるため， 測定中に巨視的な塑性変形は見られない。乙かし，内部摩擦の 值がひずみ振幅に依存する場合には，材料の力学応答が非線形 であり，微視的にい党ば応力ーひずみ曲線がヒスデリシスを描 くことを意味している.つまり, 内部摩擦の振幅依存性は力学 的ヒステリシスに起市る現象であるが(4)-(6)，従来の研究で はそれぞれ相互に独立な現象として报われてきた (1)-(3)(7)-(9).

† 1991年10月日本金属学会秋期大会に括いて発表 计 名古屋工業大学大学院生
このような微小塑性に関する研究の多くは金属材料を対象に したものであり，セラミックスの上らな脆性材料についての研 究は西方り行われていない(6)(10). 最近, Nishinoら(10)はクラ ックを含むアルミナについて内部摩擦の振幅依存性を調べ， セ ラミックスにおいても破壊の前駆現象として金属のような塑性 変形が生じていることを指摘した。ささらに，微小塑性理論(4) 基づいて, 内部摩掽の振幅依存性データを解析し，セラミック 又の微小塑性領域比拈ける力学応答を定量的に評価した。一 方，セラミックスの力学的七ステリシスについてはこれれて 直接観察された例(6)はめりない，そのため，力学的とステリ シスと内部摩擦の振幅依存性との現象的な相互関係については ほとんど明らかにされていない。

本研究では, 代表的なセラミックスとしてアルミナを取り上 げ，破壊の前駆過程をモデル化するために，熱衝撃によってマ イクロクラックを導入した。 これらの試料について曲げ試験に より力学的ヒステリシスを検出し，同一試料に詨して内部摩摖 の振幅依存性を測定した．とくに，ヒステリシスループの形状 に着目してひずみ振幅の影響を系統的に調へ，内部摩摖の振幅 依存性と比較して現象的な相互関系を検討した。 また，観測さ れた力学的ヒステリシスに対する敞小塑性理論により, 内部摩 擦データを解析して $10^{-9}$ 程度の塑珄ひずみを応力の関数とし て算出したこのよらな塑性ひずみと応力の関係は，通常の引 張試験で得られる応力-ひずみ曲線に対応するるのであり，こ の結果をもとにアルミナの锴小塑性を定量的に評価した。 


\section{II. 実 験 方 法}

試料には純度 $99.5 \%$ のルミナ基板(NTK, HA995)を用い， ダイヤモンドカッターにより $80 \times 10 \times 1 \mathrm{~mm}^{3}$ のサイズに成形 した。熱衝撃試験は，試料を炉内で目的温度委で加熱して 3.6 $\mathrm{ks}$ 保持後, $273 \mathrm{~K}$ の氷水中に投下して急冷することで行った。 このときの熱衝撃温度差 $(\Delta T)$ を变化させることによりクラッ クの量を制御した。十分に乾燥させた試料について，まず内部 摩擦を測定し，その後，同一試料炆して力学的ヒステリシス を観察した.

力学的上ステリシスの観察は負荷-除荷を1サイクルとした 曲げ試験により行った。繰返し負荷-除荷变形は,インスト口 ン型試験機を用いてスパン長さ $50 \mathrm{~mm} の 3$ 点曲げ試験で行 い,このとさの変形速度は $0.5 \mathrm{~mm} / \mathrm{min}$ で一定とした。試料 中央部の最大たわみ变位の測定には差動卜ランス(島津, DT2S-SP)を用い, 荷重と変位を X-Y レコーダによって同時に記 録した。

内部摩擦の測定は室温, 大気中に㨟いて, $1500 \mathrm{~Hz}$ 前後の自 由端横振動法で行った。実際には，試料を一定振幅で $60 \mathrm{~s}$ 間 振動させた後, 励振を止め, 自由減衰の時間变化を減哀曲線之 してレベルレューダ(Onsoku, ORL-20)に記録した。このよう な減袁曲線は振動振幅の対数值を時間に対して記録したもので 两り，1本の減衰曲線に打いて，それぞれの振動振輻に拉ける 接線の傾きを読みとることで対数減衰率を算出した。 また，内 部摩擦の測定では実験变数として試料中央部の最大ひずみ振幅 を用いた。

\section{III. 実 験 結 果}

\section{1. 力学的ヒステリシス}

著者らはこれまでに，クラックを含むアルミナについて絽返 し負荷-除荷変形を行い, 得られた力学的七ステリシスの物理 的意味を明らか炕した ${ }^{(6)}$ 。とくに，熱衝撃によってクラックを 導入した試料に打いては，応力とひずみの関係は非線形とな り，亦たか子塑性変形が起きているような挙動を示すことがわ かった。ささらに，繰返し変形によって閉じたループを形成し， 最終的には形状の変化しない定常化したヒステリシスループと なることを確認した. しかし，このような力学的ヒステリシス と内部摩擦の振幅依存性との現象的な相互関俰については明ら かルされていないそこで本研究では，繰返し負荷一除荷変形 によって得られた定常的なヒステリシスループに着目しルー プ形状に対するひずみ振幅の影響について詳細に調べた。

Fig. $1 \mathrm{~K}, \Delta T=400 \mathrm{~K}$ の熱衝撃を与光た試料について，一 定荷重のもとでの繰返し変形によるとステリシスの形状変化を 示す. 図の縌軸と横軸は, 実測值である荷重とたわみ変位で示 したが，それぞれ応力とひずみに対応するものである：これか ら，1回目の負荷-除荷サイクルにおいては，除荷後に大きな 残留ひずみ老生じていることがわかる、すなわち，変形の初期 段階ではクラックの伝播のような不可逆的な内部状態の変化が 起きていると考光られる。しかし，5回程度の繰返しによって 閉じたループを形成し，その後100回までの綝返し変形を行っ

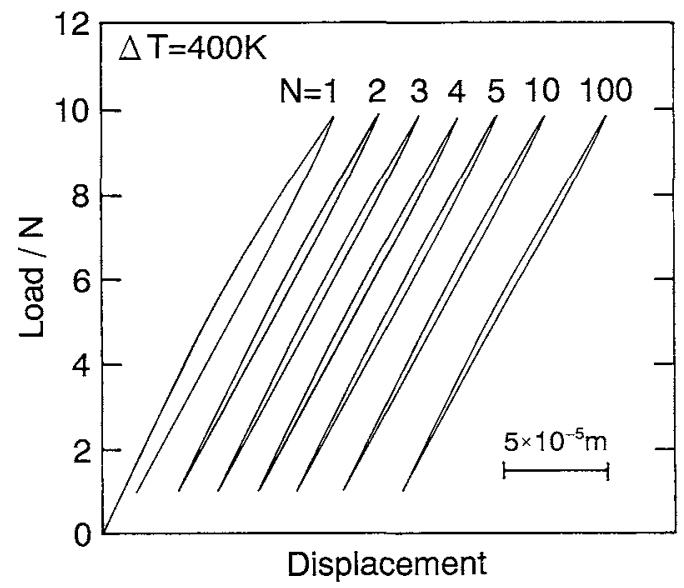

Fig. 1 Series of hysteresis loops under loading-unloading cycles for alumina subjected to thermal shock of $\Delta T=400$ $\mathrm{K} ; N$ denotes the number of cycles. The specimen was cyclically loaded to the same load level of $9.8 \mathrm{~N}$ but not unloaded completely; the bias load was $0.98 \mathrm{~N}$.

て舟破壊することはなく，同一形状のヒステリシスループが再 現性よく得られた。この100回目のヒステリシスループについ て詳紐炕見てみると，10回目のループと形状，面積ともには ぼ一致していることがわかった。このことは，10回程度の繰 返し変形によってヒステリシスループがすでに定常化している ことを示唆している。このような結果は，金属の繰返し変形で 観察されている現象と極めてよく似たるのである(1)-(3). Fig. 2 に, 各種の温度差 $(\Delta T)$ の熱衝擊を与えた試料について定常 化したとスデシシスループを示す．参考のために， $\Delta T=600$ $\mathrm{K}$ の試料の結果も示してある. $\Delta T=200 \mathrm{~K}$ の試料では, クラ ックは導入されていないので応力とひずみの関俰は線形とな り，熱衝撃を与兄ていない試料と同様に弾性的挙動を示した。

しかし，熱衝撃温度差が大さくなる任ど定常ループの幅や面積 が大きくなり，また，見かけのヤング率が低下していることが わかる.

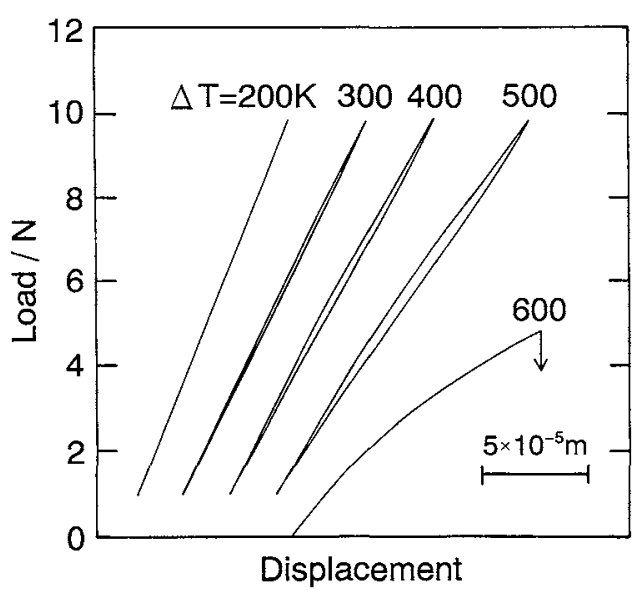

Fig. 2 Stabilized hysteresis loops under a loading-unloading condition for alumina subjected to thermal shock; $\Delta T$ is the quenching temperature difference. The specimens were cyclically loaded to the load level of $9.8 \mathrm{~N}$. 


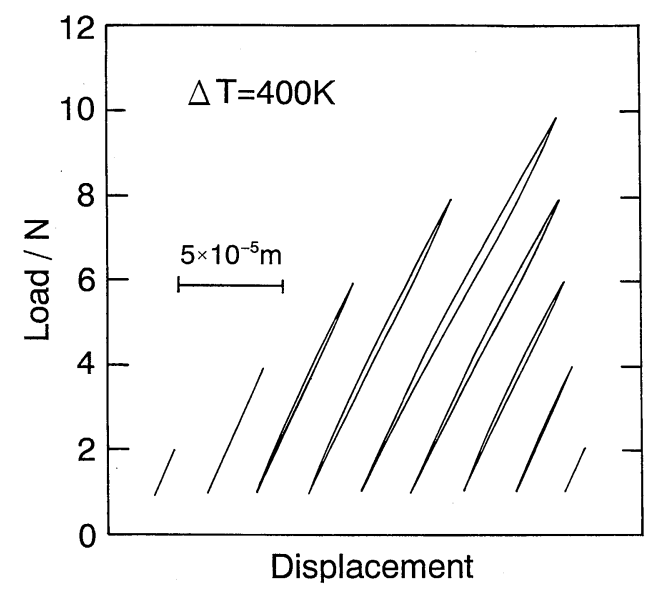

Fig. 3 Series of stabilized hysteresis loops under a loading-unloading condition for alumina subjected to thermal shock of $\Delta T=400 \mathrm{~K}$. The specimen was cyclically loaded as a function of strain amplitude.

次に, ひずみ振幅の増加過程および減少過程に执いて,ルー プ形状におよぼすひずみ振幅の影響を調べた. $\Delta T=400 \mathrm{~K}$ の 試料について，各ひずみ振幅で得られた定常ループを Fig. 3 に示す.ひずみ振幅の増加過程では，いずれのひずみ振幅でも 1 回目の負荷-除荷サイクルによって残留ひずみを生じ, 開い たヒステリシスループが得られた。しかし，各ひずみ振幅での 繰返し変形によって閉じたループを形成し，最終的には Fig. 3 に示すように一定の形状を持つ定常ループとなった。この図 から, ひずみ振幅が大きくなるに伴って, 定常ループの幅や面 積が増加していることがわかる，一方，ひずみ振幅の減少過程 では, 1 回目の負荷-除荷サイクルに怙いて閉じたループを形 成し，その後の繰返し変形によってもループ形状はほとんど変 化しなかった．このときのループの形状は，ひずみ振幅の増加 過程に括ける定常ループと比較して大きな違いは見られず，同 一のひずみ振幅で比較するとループ面積はほとんど一致してい た.

\section{2. 内部摩擦の振幅依存性}

Fig. 4 は, 熱衝撃温度差 $(\Delta T)$ の異なる試料について, 内部 摩擦のひずみ振幅に対する変化を測定した結果である.ここで 用いた試料はFig. 2 に示したものと同一であるが，内部摩擦 の測定は負荷-除荷試験の前に行った。熱衝撃を与えていない アルミナの内部摩擦は, 図中に点線で示すように $3 \times 10^{-4}$ 之 非常に小さく, またひずみ振幅に対する変化は見られなかっ た.クラックを含むアルミナについて内部摩擦を測定した結果 は，次のようにまとめることができる．

(1) 振幅に依存しない内部摩擦は， $\Delta T$ が増加すると著しく 大きくなる.

（2）振幅に依存する内部摩擦は， $\Delta T$ が増加すると大きくな り,さらに振幅に対する変化も急激になる。

(3) 内部摩擦が振幅に依存し始める点は, $\Delta T$ の増加に伴っ て低振幅側へ移行する.

以上の結果は, 熱衝撃を与えたアルミナについて従来から報 告されている結果 ${ }^{(9)(10)}$ とも一致している. 今回の内部摩擦の

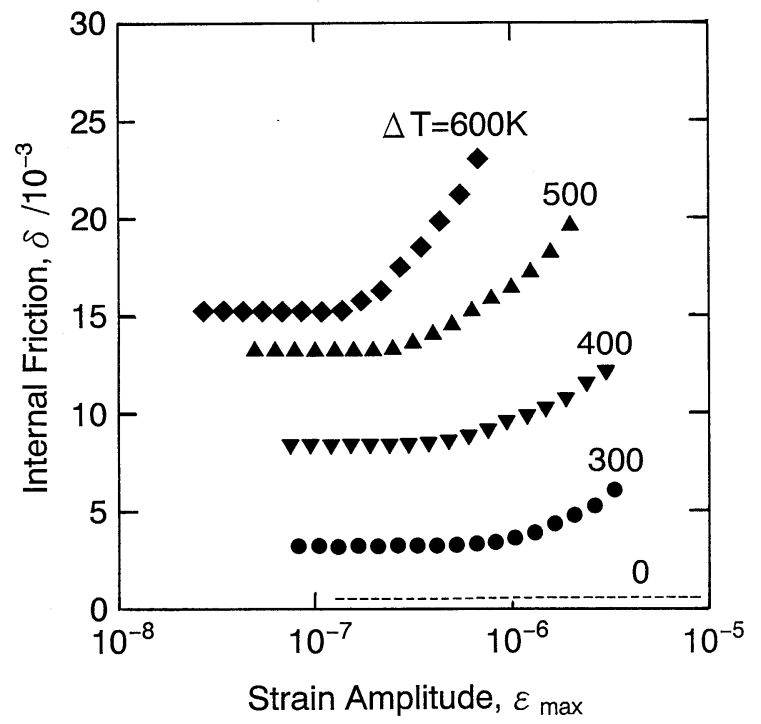

Fig. 4 The measured value of internal friction $\delta$ plotted against the maximum value of strain amplitude $\varepsilon_{\max } \Delta T$ is the quenching temperature difference.

測定は $10^{-6}$ のオーダーのひずみ振幅で行われて特り，そのひ ずみ領域は力学的ヒステリシスの観察に比べて 2 桁ほど小さ いものである.しかしながら，本研究ではこれらの測定を同一 の試料について行っているため, 内部摩擦の測定結果と力学的 ヒステリシスの観察結果とは定性的には対比することができ る.

\section{N. 考察}

\section{1. カ学的ヒステリシスと内部摩擦の相互関係}

内部摩擦の測定值である対数减衰率 $\delta$ は, 物理的には次の ようなェネルギー表現によって意味づけられる。

$$
\delta=\frac{\Delta W}{2 W}
$$

ここで, $W$ は振動体の力学的エネルギーであり， $\Delta W$ は振動 1 サイクルあたりの損失エネルギーである．とくに， $\Delta W$ は荷 重-変位曲線上に描かれるヒステリシスループの面積に等しく なる.このことは, 内部摩擦が力学的ヒステリシスに起因する 現象であることを意味している.つまり, Fig. 3 と Fig. 4 の 観察結果は相互に関係するものであるが，両者を直接比較する のは困難である．そこで，内部摩擦データに対応するように， Fig. 3 で得られた各ヒステリシスループの面積を試料中央部の 最大ひずみ振幅に対してプロットした結果を Fig. 5 に示す. 内部摩擦の振幅依存性は 1 本の減衰曲線から求められるので, ループ面積の計算にはひずみ振幅の減少過程で得られたヒステ リシスループを用いた. Fig. 5 に扔いて, 熱衝撃温度差の大き い試料ほど各ひずみ振幅でのループ面積が大きく，また，ひず み振幅に対するループ面積の増加も顕著になっている. このよ らなひずみ振幅依存性は Fig. 4 の内部摩擦の結果と定性的に 一致している.

ところで, 力学的ヒステリシスの観察は内部摩擦の測定に比 


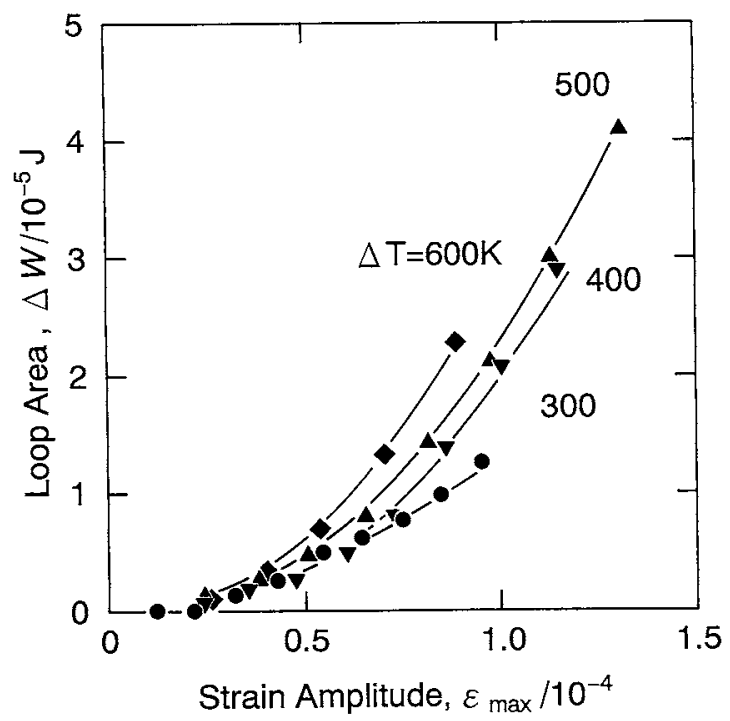

Fig. 5 The area of stabilized hysteresis loop $\Delta W$ plotted against the maximun value of strain amplitude $\varepsilon_{\max } . \Delta T$ is the quenching temperature difference.

べて2桁も大きいひずみ領域で観察されているが，ヒステリ シスの測定精度は内部摩擦に比べてあまりよくないという問題 がある、そのため，七ラミックスに执ける微小塑性を定量的に 評価するに性，内部摩擦の振幅依存性デ一タを解析することが 必要となる。

\section{2. 内部摩擦の振幅依存性の解析}

内部摩擦の振幅依存性は振動变形でのみ意味を持つ力学応答 であるが，微小塑性理論(4)によりデータ解析することにより， 引張試験で得られるよらな塑性ひずみと応力の関係に換算する ことができる(10)-(13)。この場合，特定の転位モデルを仮定す ることなく現象のみに着目してデータ解析を行うので，金属に 限らず，セラミックスに対しても適用することができる(10). データ解析侮しては, まず力学的ヒステリシスの形状を規定 しておかなければならない，今回の観察結果から，せラミック スに和けるヒステリシスループは，振動 1 サイクルに対して 1 つの閉じたループを示しており，また，その形状は離脱型の 上らに非対称なものではなく、をしろ摩擦型のように対称形で ある(4)(6)ことがわかる。この上うな形状のとステทシスループ は，アルミナの負荷除荷サイクルルよるクラックの開口変位 と荷重の関係炕おても観察されている(14)。つまり，也ラミ ックスに括いても，微小なひずみ領域では金属(1)-(3)やイオン 結晶(15) と同様に摩擦型ヒステリシスが実現していることが結 論できる。

Nishino ら ${ }^{(10)}$ は以前に，七ラミックスに扣ける内部摩擦の 振幅依存性データを解析し，塑性ひずみを応力の関数として算 出した。今回は，実測された摩擦型ヒステリシスに対する微小 塑珄理論により, Fig. 4 亿示した内部摩擦の振幅低存性データ を解析した. Fig. 6 は塑珄ひずみ $\varepsilon_{\mathrm{p}}$ と応力 $\sigma$ の関係を表して いるが，通常の応力ーひずみ曲線とは違って縦軸と横軸が逆に なっている.これから，1 $\mathrm{MPa}$ 程度の変形応力のもとで $10^{-9}$

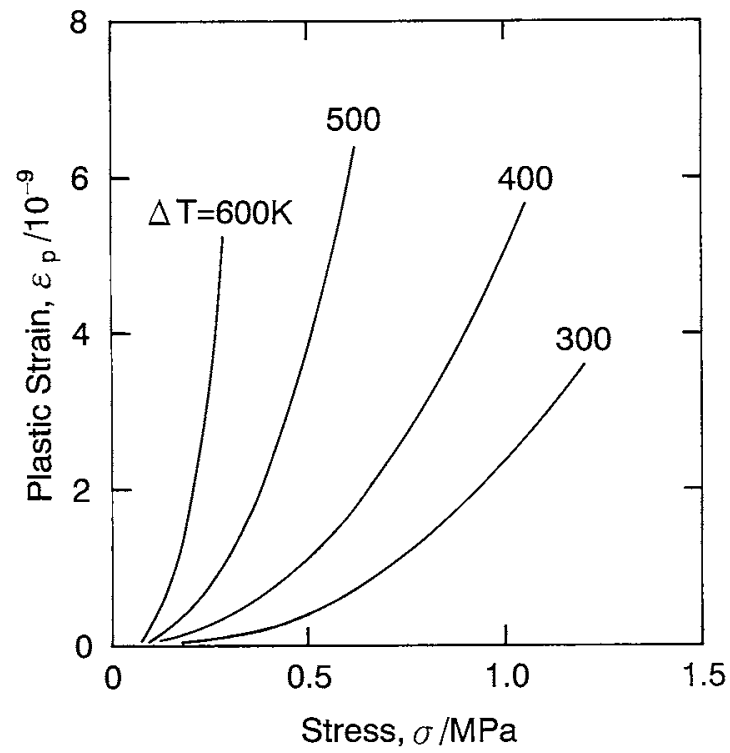

Fig. 6 The microplastic strain $\varepsilon_{\mathrm{p}}$ expressed as a function of stress $\sigma . \Delta T$ is the quenching temperature difference. The curves are obtained from the results in Fig. 4.

のオーダーの塑性ひずみが非線形に増加していくことがわか る、すなわち，微細なクラックが導入されたセラミックスにお いて，通常の弓張試験では検出できないほど微小な塑性変形が 生じていることを示している。しかも，このような微小塑性領 域比いても，ATが大きくなる伍ど応力てずみ曲線は低応 力側ヘシフトしていくことがわかる.この応力低下の傾向は, これまで破壊試験により調べられてきているように，熱衝撃を 受けると破壇強度が著しく低下する(16)(17)ことと定性的には一 致している.

内部摩擦の実験では，測定中に内部状態が变化しないように 1 回の振動減衰過程に着目して揤定を行っている.さらに，内 部摩擦の測定値は繰返し湘定によっても变化しないことから， 測定中以クラックの発生や伝播など不可逆な变化は起きていな いと考光られる。したがって，内部摩摖の測定は，微小なひず 夕領域に扎ける力学応答を非破壊で精度よく検出できるので， セラミックスのような脆性材料の非破壊試験としても有効な方 法である。

\section{V. ま と め}

本研究では, クラックを含さアルミナについて力学的ヒステ リシスを観察し，さらに内部摩摖の振幅依存性と対比して現象 的な相互関係を検討した，得られた結果は次のよらにまとめら れる。

（1） $10^{-4}$ 程度のひずみ領域に括ける負荷-除荷サイクルによ り，応力ーひずみ曲線上にヒステリシスループが観察された。 とくに，変形初期には除荷後に永久ひずみを生じたが，絽返し 変形により閉じたヒステリシスループが定常的に得られた。つ 暒り，七ラミックスの破壞前駆過程に粉いては金属のよらな微 小塑性が生じている。 
（2）定常ループの形状から判断して摩擦型のヒスデシンスが 実現している。これは，金属や合金で観察されているものと同 じである。

（3）定常ループの面積はひずみ振幅とともに著しく増加し， 現象的には内部摩擦の振偪依存性と対応している。また，ひず み振幅の増加過程に打ける定常ループと減少過程で得られたル 一プの形状に大きな違いは見られなかった。

(4) 内部摩擦の振幅低存性データを微小塑性理諭见より解析 し，10-9 程度の塑性ひずみを応力の関数として算出した。こ のような徽小塑性領域比扣りる变形応力の变化は, クラックの 発生や伝播による破填強度の低下之定性的には一致している。

本研究の一部は, 名古屋工業大学共同研究センターの研究プ ロジェクトとして的ファインセラミックスセンターとの共同研 究により行われたことを付記し，関係各位に謝意を表する。

\section{文献}

(1) J. M. Roberts and N. Brown: Trans. AIME, 218(1960), 454.
(2) N. Brown and R. A. Ekvall: Acta Metall., 10(1962), 1101.

(3) P. Lukáš and M. Klesnil: Phys. Stat. Sol., 11(1965), 127.

(4) S. Asano: J. Phys. Soc. Japan, 29(1970), 952.

(5) N. Brown: Microplasticity, Ed. by C. J. McMahon, Jr., John Wiley \& Sons, New York, (1968), 45

(6) Y. Nishino, H. Ogawa and S. Asano : Phil. Mag. Lett., 66(1992), 313

(7) V. A. Chelnokov, V. A. Stepanov and N. L. Kuz'min: Sov. Phys. Solid State, 12(1970), 649.

(8) R. B. Schwarz and L. L. Funk: Acta Metall., 31(1983), 299 .

(9) K. Matsushita, S. Kuratani, T. Okamoto and M. Shimada: J. Mater. Sci. Lett., 3(1984), 345

(10) Y. Nishino, T. Murayama and S. Asano : Phil. Mag. A, 65(1992), 1187

（11）奈良井 弘，浅野 滋：日本金属学会誌，46(1982)，253.

(12) 後藤肇, 西野洋一, 浅野滋: 日本金属学会誌, $\mathbf{5 5}(1991), 848$

(13) Y. Nishino, Y. Okada and S. Asano: Phys. Stat. Sol. (a), $129(1992), 409$.

(14) G. Vekinis, M. F. Ashby and P. W. R. Beaumont: Acta Metall. Mater., 38(1990), 1151.

(15) S. B. Kustov, S. N. Golyandin and B. K. Kardashev: Sov. Phys. Solid State, 30(1988), 1248.

(16) D. P. H. Hasselman: J. Am. Ceram. Soc., 52(1969), 600.

(17) D. P. H. Hasselman: J. Am. Ceram. Soc., 53 (1970), 490. 